\title{
A Snapshot of Error Buzzwords on Facebook Trading Groups
}

\author{
Antonius Setyawan Sugeng Nur Agung ${ }^{1,}{ }^{*}$, Monika Widyastuti Surtikanti ${ }^{2}$, \\ Masfa Maiza ${ }^{3}$
}

${ }^{1,2,3}$ STKIP Pamane Talino, Indonesia

${ }^{*}$ Corresponding author. Email: antonius.setyawan.007@gmail.com

\begin{abstract}
The 4.0 growing Industry pushes trading and marketing into the digital market. Facebook allows everyone to stay connected virtually. During the COVID-19 pandemic, Facebook has become a popular digital market. The use of English dictions is booming in marketing promotion as and it is widely used by millennial online marketers in West Borneo when promoting their products using buzzwords. The data in this study were taken from one year of document observation in several online trading groups on Facebook. The study aims at finding out the error used by online marketers when posting their promotions. The study found that they used English as a "trend" rather than creating buzzwords. The in-depth interviews found that online marketers did not realize that they have used inappropriate words. The correct writing of it is often neglected without any correction as long as it sounds English and commonly used. The results of this study may reflect the language used-error analysis in future studies. Moreover, educating millennial-online marketers is considered beneficial for the sake of language politeness.
\end{abstract}

Keywords: Buzzwords, Facebook, Millennial-online marketers, Words of errors

\section{INTRODUCTION}

The use of English reaches its popularity nowadays and globalization may be the sole reason for this change. The competition in the global market is more competitive due to the rise of new technology, business processes, and the application of the global supply chain (Gubán, \& Kovács, 2017). Reflecting on the data of the Consumer Confidence Index, Indonesia got 119 points indicating a high level of customer confidence in shopping (Bismo et al., 2020). This data shows that Indonesian people are willing to spend their money on shopping transactions. Moreover, Indonesia ranks 62 in the globalization index rank (Vaish, 2010). The use of English in education, trading, and society is still limited despite the fact that English is a popular lingua franca (Majhanovich, 2014).

Somehow, English is neither the first nor the second language especially in Landak Regency, West Borneo. Here, English as a foreign language is still considered an alien language because of its status and difficulties (Agung, 2019). However, the trend in using error English buzzwords on Facebook trading groups when the millennial-online marketers promoting their posts is the basic issue of this research.

\subsection{Facebook Trading Groups}

Technology has become a fabric of our everyday life and its presence is unavoidable to ease our lives. The presence of the internet makes it more and more unbearable. The shape of traditional trading is now shifting during the successive technology development in industry 4.0. The concept of trading or offering goods has evolved digitally. In line with it, Schwab stated that digitalization is one of the major influences on the inter-industry business ecosystem (Schwab, 2016; Soedarsono et al., 2020). Business is now digitalized. Facebook has been used significantly by its major users as a digital marketing tool (Kamal, 2016). Digital marketing is needed by modern marketers because it can perform marketing activities effectively and still low-cost budget (Herttua et al., 2016). Moreover, nowadays e-marketing influences the consumers in purchasing decisions to buy the product (Widodo et al., 2017).

The COVID-19 pandemic increases this trend since people feel safer if they avoid the crowd for the sake of physical distancing. This paradigm defines the existence of marketplaces and online trading groups which can achieve their popularity not only in big 
cities but also in the urban areas of the least-developed region. Nowadays, more and more millennial traders in West Borneo use Facebook to promote their products and kinds of stuff. A new business model has been enhanced by Facebook, the internet, and the pandemic of COVID-19. Nowadays, digital markets via Facebook trading groups are everywhere ubiquitous. Several groups have been detected as large groups by having huge members.

\subsection{Facebook Trading Groups}

As members of those groups, the researchers noticed a similarity in their posts. There is a trend to write the promotion posts in mixed language, especially English dictions. In marketing theories, the use of buzzwords is considered essential in marketing. According to (Wilson, 2000) both viral marketing and creating a buzz is the same concept of promoting interestingly. Buzzwords become interesting and effective because it is becoming self-identity for a group of millennials while shopping (Hamilton, 2018). It seems that buzzwords give pride of value to trigger certain consuming behavior.

In a wider scope, the existence of buzzword is imperious not only in marketing but also in many aspects of life. The buzzwords are used in modern sports training as discourse instructions (Yarmolinets et al., 2017). Even in tourism sustainability in Asia, buzzwords are important in protecting local communities (Haya, 2008; Herman et al., 2016 in Setiawan \& Wiweka, 2018). Another study shows that buzzword is important in shaping the brand image and influencing the purchasing decision (Anggadwita et al., 2020). Referring to those previous theories, buzzwords in this research are best described as a unique word that represents the special identity of a brand image to reinforce the promotion of a product. In line with it, in West Borneo more and more millennial-online marketers from various educational backgrounds are keen on using English dictions when posting their promotion. Do they intentionally use it as a buzzword or just beautify the promotion? To be able to answer this question, the researchers are interested in mapping the errors in their posts on Facebook. Thus showing how social phenomena in writing English dictions as a buzzword is mirrored in this paper.

The use of mixed languages between local languages and English when the millennial marketers post their promotion in Facebook trading groups seems very likely so does the error in writing the English dictions and buzzwords. The previous study found that "local" buzzwords are part of the millennial generation (Hamilton, 2018). This theory may explain the use of mixed languages in marketing promotion. The language itself is shaped by the environment where the speaker geographically occupies (Alidmat \& Manjet, 2020). Globalization breaks this boundary since it has been previously said that the use of English is not common in West Borneo. In this case, the presence of errors in English dictions is predicted. Somehow there is a trend among them to use English buzzword when posting on Facebook.

The researchers believe that investigating and mapping the error is very important to do. It is worth trying because the millennial-online marketers in West Borneo need to know how to write the correct English dictions and buzzwords in their posts. Writing errors in using dictions and buzzwords lead to wrong translation and interpretation. If it does, the purpose of creating interesting promotions fail to achieve their goals. It may lead people to lose the message of the promotion. Such expression like "baju import kite readi, realpick" is representing mixed languages: realpick, import, and readi represent English language, baju represents Indonesian, and kite represents Malay. That expression means "our imported clothes are ready, real picture".

Investigating such errors in writing the English dictions and buzzwords is the sole concern in this research. Mapping and correcting the errors are dedicated to giving an educational contribution to society in the form of providing correct dictions for the sanctity of language politeness. The perspective of language politeness is influenced by the cultural perspectives among the culture (Etae et al., 2016). From a wider perspective, the alliance between language politeness and local culture lies in the regular pattern of the language choice in interaction (Brown, 2015). Notably, in writing, readers may perceive negatively grammatically flawless (Maier, 1992). Therefore, investigation and analysis of the errors in this research go with the collection of the corrected words of errors, the discussion of it, and the slight chance of it concerning language politeness.

\subsection{The Phenomena of Using English Buzzwords in Facebook Trading Groups}

As the members of those groups, the researchers noticed a similarity in their posts. There is a trend to write the promotion posts in mixed language, especially English dictions. In marketing theories, the use of buzzwords is considered essential in marketing. According to (Wilson, 2000) both viral marketing and creating a buzz is the same concept of promoting interestingly. Buzzwords become interesting and effective because it is becoming self-identity for a group of millennials while shopping (Hamilton, 2018). It seems that buzzwords give pride of value to trigger certain consuming behavior. 
In a wider scope, the existence of buzzword is imperious not only in marketing but also in many aspects of life. The buzzwords are used in modern sports training as discourse instructions (Yarmolinets et al., 2017). Even in tourism sustainability in Asia, buzzwords are important in protecting local communities (Haya, 2008; Herman et al., 2016 in Setiawan \& Wiweka, 2018). Another study shows that buzzword is important in shaping the brand image and influencing the purchasing decision (Anggadwita et al., 2020). Referring to those previous theories, buzzwords in this research are best described as a unique word that represents the special identity of a brand image to reinforce the promotion of a product. In line with it, in West Borneo more and more millennial-online marketers from various educational backgrounds are keen on using English dictions when posting their promotion. Do they intentionally use it as a buzzword or just beautify the promotion? To be able to answer this question, the researchers are interested in mapping the errors in their posts on Facebook. Thus showing how social phenomena in writing English dictions as a buzzword is mirrored in this paper.

The use of mixed languages between local languages and English when the millennial marketers post their promotion in Facebook trading groups seems very likely so does the error in writing the English dictions and buzzwords. The previous study found that "local" buzzwords are part of the millennial generation (Hamilton, 2018). This theory may explain the use of mixed languages in marketing promotion. The language itself is shaped by the environment where the speaker geographically occupies (Alidmat \& Manjet, 2020). Globalization breaks this boundary since it has been previously said that the use of English is not common in West Borneo. In this case, the presence of errors in English dictions is predicted. Somehow there is a trend among them to use English buzzword when posting on Facebook.

The researchers believe that investigating and mapping the error is very important to do. It is worth trying because the millennial-online marketers in West Borneo need to know how to write the correct English dictions and buzzwords in their posts. Writing errors in using dictions and buzzwords lead to wrong translation and interpretation. If it does, the purpose of creating interesting promotions fail to achieve their goals. It may lead people to lose the message of the promotion. Such expression like "baju import kite readi, realpick" is representing mixed languages: realpick, import, and readi represent English language, baju represents Indonesian, and kite represents Malay. That expression means "our imported clothes are ready, real picture”.
Investigating such errors in writing the English dictions and buzzwords is the sole concern in this research. Mapping and correcting the errors are dedicated to giving an educational contribution to society in the form of providing correct dictions for the sanctity of language politeness. The perspective of language politeness is influenced by the cultural perspectives among the culture (Etae et al., 2016). From a wider perspective, the alliance between language politeness and local culture lies in the regular pattern of the language choice in interaction (Brown, 2015). Notably, in writing, readers may perceive negatively grammatically flawless (Maier, 1992). Therefore, investigation and analysis of the errors in this research go with the collection of the corrected words of errors, the discussion of it, and the slight chance of it concerning language politeness. context.

\section{RESEARCH METHODS}

This case study used document analysis as a qualitative research methodology. The primary data were collected from the posts in online-private Facebook trading groups in West Borneo within a oneyear observation. The secondary data were gathered by using purposive sampling through an online interview that triangulation can be achieved. According to (Bowen, 2009) document analysis is a systematic procedure for reviewing and evaluating both printed or electronic including internet-transmitted material. Document analysis applies to such a qualitative case study like this (Johnson \& Stake, 1996).

The blueprint of this research uses an adopted Yazan's model of the juxtaposition of three case study approaches in Yin, Merriam, and Stake (Yazan, 2015). This model involves five stages of case designing- data gathering- data analyzing- data triangulation- and conclusion. The framework consists of the following steps as it is shown in table 1 .

Table 1. The developed blueprint for mapping the words of errors

\begin{tabular}{|c|l|l|l|}
\hline No & The Stages & \multicolumn{1}{|c|}{ The Actions } & \multicolumn{1}{|c|}{ The Results } \\
\hline 1 & Case designing & Sharpening the issue & The sharpened issue \\
\hline 2 & Data gathering & $\begin{array}{l}\text { Observing the } \\
\text { documents }\end{array}$ & Documents observation \\
\hline 3 & Data analyzing & $\begin{array}{l}\text { Mapping } \\
\text { the error }\end{array}$ & The mapped error \\
\hline 4 & $\begin{array}{l}\text { Data } \\
\text { triangulation }\end{array}$ & Interviewing & The triangulated data \\
\hline 5 & Conclusion & Interpreting & The findings \\
\hline
\end{tabular}

Case design points out the connection among the logical sequence, empirical data, research question, and the conclusion. In determining the case design, the 
researchers had the preliminary study to observe the phenomena happened in the Facebook trading. The analysis in the preliminary study was used to formulate the issue. The next stage is gathering the data through documents. The researchers identified the data focusing on the buzzword's errors realized in the Facebook Trading market namely "Jual-Beli Ngabang Landak", "Ngabang Jual Beli", and "Jual Beli Tanah dan Property Pontianak Kalimantan Barat”. These three Facebook trading markets are popularly used by West Borneo Facebook users. After gathering the data, the researchers examined the lexical errors of the buzzwords based on the correct spelling in the English dictionary. To validate the data, the researchers had the in-depth interview to the Facebook marketers. The list of questions was design to examine the factor influencing the errors. Finally, the gathered data were analysed to formulate the interpretation.

\section{DATA AND DATA COLLECTION}

Electronic documents involving one-year observation in three different Facebook trading groups are the main data sources in this research. More descriptions of the characteristics of the groups can be seen in table 2 . The primary data was collected using document observation which produced the collected data of the words of errors in each group. The secondary data was gathered by conducting two indepth interviews from each group. They were selected purposively under such criterion: posting/ buying actively.

Table 2. The characteristics of the groups

\begin{tabular}{|c|c|c|c|}
\hline No & The Groups & Total Members & Average Post/ Day \\
\hline 1 & Group 1 & 26.379 & $110-120$ \\
\hline 2 & Group 2 & 63.088 & $90-100$ \\
\hline 3 & Group 3 & 117.119 & $100-110$ \\
\hline
\end{tabular}

The document analysis was done by mapping and clustering the use of error dictions on the posts. Similar words of errors were only counted once but the variants of the error were clustered.

\section{RESULT AND DISCUSSIONS}

The mapped error from the result of the analysis of the documents found 311 words of errors (105 in group one, 103 in group 2, and 103 in group 3). When they were sorted by clustering the meaning based on the correct words, 56 similar words were omitted. As a result, 255 of the clustered words of errors remain under 497 variations of the words of errors. Table 3 shows the calculation of words' error realized in West Borneo's Facebook trading.
Table 3. The calculation of word's errors

\begin{tabular}{|c|c|c|c|c|}
\hline $\begin{array}{l}\text { Gro } \\
\text { up }\end{array}$ & $\begin{array}{l}\text { Number } \\
\text { of errors }\end{array}$ & $\begin{array}{l}\text { Number } \\
\text { of the } \\
\text { unsorted } \\
\text { errors }\end{array}$ & $\begin{array}{l}\text { Number } \\
\text { of the } \\
\text { Sorted } \\
\text { errors }\end{array}$ & $\begin{array}{c}\text { Variation } \\
\text { of the } \\
\text { words of } \\
\text { errors }\end{array}$ \\
\hline G1 & 105 & \multirow{3}{*}{311} & \multirow{3}{*}{$\begin{array}{c}255 \\
\text { (clustere } \\
\text { d words) }\end{array}$} & \multirow{3}{*}{$\begin{array}{c}497 \\
\text { (words } \\
\text { errors) }\end{array}$} \\
\hline G2 & 103 & & & \\
\hline G3 & 103 & & & \\
\hline
\end{tabular}

Previously, it has been said that in marketing, buzzwords are best described as a unique word that represents the special identity of a brand image to reinforce the promotion of a product. Selecting from the 255 clustered and sorted words found, there were only 10 dictions could be categorized as buzzwords. They were listed as follows: best seller, big sale, flash sale, grade A, green family, greenhouse, green mansion, modern concept, organic, and original. These dictions have a unique identity to empowering the conceptual image or the advertised products. As an example, the term "greenhouse, green mansion, and green family" representing eco-living. The promotion is dedicated to people who are seeking an environmental place of living. These findings have a close relationship with linguistics studies in the advertisement. The function of linguistics in an advertisement should be taken into account by the advertiser to appeal to consumers. Leech in Strang (1968) called this as lexical strategy. Lexical strategies emphasize the word formation in a phrase or sentence. Besides, an adjective is commonly used in the advertisement (Baharum et al., 2019). The adjective presents a clear sense of the modification of a noun or pronoun. Since words are very powerful for advertisement, then it should be created as well as possible to create a positive image for consumers. Another example, the term "grade A" can be found easily not only in the promotion of fashion products but also in the sale of shrimp-like in "grade $A$ prawns". Local people will directly know that the white water jumbo prawns are being advertised. This is in line with (Hamilton, 2018) that the millennial generation tends to use "local" buzzword.

Meanwhile, the other 245 clustered words do not represent a buzz. They are used because there is a trend to use mixed languages. Referring to Gubán and Kovács, the global market is enhanced by globalization (Gubán \& Kovács, 2017), that trend is true in the case of West Borneo.

According to the interview results, the interviewed marketers did not know that they have made error writing on the use of certain English words in writing their regular promotions. They thought that they were writing it correctly. Mostly they just imitating other sellers post or words they have heard without enough 
competence to check the spelling of the correct words. It is unintentionally mistake. However, the error is the efficacy of delusion in interpretation. As an example, a post on property as it is found on data 1:144, the term Liter $U$ in 'Free pagar Liter $U$ ' is hard to be interpreted correctly without knowing the context. Figure 1 shows the erros in writing the term Liter $U$.

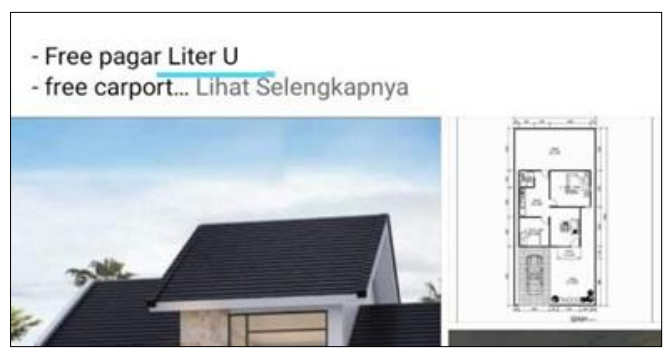

Figure 1. The example of the post

The word liter may refer to an English diction letter. Somehow, 'Litter $U$ ' is a non-technical diction. This diction seems to be nowhere in mechanical and architectural terms. The target expresssion of 'Free pagar Liter $U^{\prime}$ is $U$-shaped fence for free.

Referring to the previous case, it reveals that writing may be perceived negatively (Maier, 1992). The readers may receive a different meaning. It may cause misinterpretation which raises the awareness of language politeness. Avoiding misunderstanding one another is an essential anchor of social politeness in the account both of the nature of humans and the ability to communicate cross-culturally (Brown, 2015). Therefore, misunderstanding towards the offered product may reduce the customers' interest in buying (Ramadanty et al., 2020). For instance, it meets the need for vocabulary education. Reading contributes to incidental vocabulary acquisition (Tan $\&$ Goh, 2020). The presence of correct vocabulary for online marketers is considered valuable because of the massive posts in Facebook trading groups.

\section{CONCLUSION}

The use of English dictions by the millennial marketers is like a word competition to play in their post of promotion on Facebook. They use it in their Facebook posts because they think it is cool and catchy. They do not even know that the words may have been written incorrectly. They do not realize that mistake; so does it is called an error. It is just a millennial trend in online marketing. The results and the correction of the errors are beneficial to educate the millennial online marketers to use better English diction to beautify their promotion. Furthermore, the methodology of research is adaptable as a guideline for future study in developing research of language usederror analysis in social media.

\section{AUTHORS' CONTRIBUTIONS}

This study was designed and coordinated by ASSNA, MWS, and MM. ASSNA had the preliminary study and portrayed the phenomena realized in Facebook trading markets in West Borneo. He also formulated the research questions, devised the main conceptual framework and gathered the data. MWS contributed in the validation of the data namely the buzzwords' errors and encouraged ASSNA to investigate the specific aspect of findings. MM processed the triangulation of the data. ASSNA wrote the full manuscript. MWS and MM had the proofreading stages. All authors contributed to the final manuscript and its revisions.

\section{ACKNOWLEDGMENTS}

Acknowledgements and appreciation to University Centre of Excellence Javanologi for Javanese Traditions Universitas Sebelas Maret.

\section{REFERENCES}

[1] Agung, A. (2019). Current Challenges in Teaching English in the Least-Developed Region in Indonesia. Current Challenges in Teaching English in the Least-Developed Region in Indonesia, 9(3), 266-271. https://doi.org/10.31940

[2] Alidmat, A.O.H., \& Manjet, K. (2020). Conflict of Culture in Translation: A Case Study of Abdelrahmanmunif's Novel Cities of Salt: AlTeeh. Pertanika Journal of Social Sciences and Humanities.

[3] Anggadwita, G., Alamanda, D.T., \& Ramadani, V. (2020). Halal Label vs Product Quality in Halal Cosmetic Purchasing Decisions. IKONOMIKA. https://doi.org/10.24042/febi.v4i2.5897

[4] Baharum, N.S., Halim, H.A., \& Hasan, R.M. \& H.Z. (2019). The Use of Lexical Strategies in the Discourse of Malaysian Advertisements. Jurnal Linguistik, 23(2), 041-050.

[5] Bismo, A., Putra, S., Sarjono, H., \& Nasrul, L. (2020). Effect of Functional Convenience and Representational Delight on Positive Emotional Effect and Impulse Buying of Discount Group Site Users in Indonesia. Pertanika Journal of Social Sciences and Humanities. 
[6] Bowen, G.A. (2009). Document Analysis as a Qualitative Research Method. Qualitative Research https://doi.org/10.3316/QRJ0902027

[7] Brown, P. (2015). Politeness and Language. In International Encyclopedia of the Social \& Behavioral Sciences: Second Edition. https://doi.org/10.1016/B978-0-08-0970868.53072-4

[8] Etae, S., Krish, P., \& Hussin, S. (2016). Politeness Strategies by Thai EFL Tertiary Learners in an Online Forum. Pertanika Journal of Social Sciences and Humanities.

[9] Gubán, M., \& Kovács, G. (2017). Industry 4.0 Conception. Acta Technica CorviniensisBulletin of Engineering, 10(1), 111.

[10] Hamilton, V.N. (2018). Determining Millennial Food Buying Preferences: Based on Product Marketing with "Buzzwords". [University of Kentucky]. https://doi.org/10.13023/ETD.2018.053

[11] Herttua, T., Jakob, E., Nave, S., Gupta, R., \& Zylka, M. P. (2016). Growth Hacking: Exploring the Meaning of an Internet-Born Digital Marketing Buzzword. In Springer Proceedings in Complexity. https://doi.org/10.1007/978-3-319-42697-6_15

[12] Johnson, K.E., \& Stake, R.E. (1996). The Art of Case Study Research. The Modern Language Journal. https://doi.org/10.2307/329758

[13] Kamal, Y. (2016). Study of Trend in Digital Marketing and Evolution of Digital Marketing Strategies. International Journal of Engineering Science and Computing.

[14] Maier, P. (1992). Politeness Strategies in Business Letters by Native and Non-Native English Speakers. English for Specific Purposes. $\quad$ https://doi.org/10.1016/S08894906(05)80009-2

[15] Majhanovich, S. (2014). Neo-Liberalism, Globalization, Language Policy and Practice Issues in the Asia-Pacific Region. Asia Pacific Journal of Education. https://doi.org/10.1080/02188791.2013.875650

[16] Ramadanty, S., Muqarrabin, A.M., Nita, W.A., \& Syafganti, I. (2020). Examining the Effect of Persuasive Message of Beauty Vloggers on Information Acceptance of Ewom and Purchase Intention: The Study of Consumers of Beauty Products in Jabodetabek, Indonesia. Pertanika
Journal of Social Sciences and Humanities.

[17] Schwab, K. (2016). The Fourth Industrial Revolution: What It Means and How to Respond. World Economic Forum.

[18] Setiawan, B., \& Wiweka, K. (2018). A Study of the Tourism Area Life Cycle in Dieng Kulon Village. Pertanika Journal of Social Sciences and Humanities.

[19] Strang, B. M. H. (1968). English in Advertising: A Linguistic Study of Advertising in Great Britain. Geoffrey N. Leech, English Language Series, General Editor, Randolph Quirk. Longmans, Green and Co., London 1966. pp. xiv, 210.25/-. In Lingua. https://doi.org/10.1016/0024-3841(68)90112-5

[20] Tan, A.W.L., \& Goh, L.H. (2020). Comparing the Effectiveness of Direct Vocabulary Instruction and Incidental Vocabulary Learning in Improving the Academic Vocabulary of Malaysian Tertiary Students. Pertanika Journal of Social Sciences and Humanities.

[21] Vaish, V. (2010). Globalization of Language and Culture in Asia: The Impact of Globalization Processes on Language. Bloomsbury Publishing.

[22] Widodo, A., Yusiana, R., \& Anggi, S. (2017). How E-Marketing and Trust Influence Online Buying Decision: A Case Study of mataharimall.com in Bandung. Pertanika Journal of Social Sciences and Humanities.

[23] Wilson, R. (2000). Demystifying Viral Marketing. Web Marketing Today.

[24] Yarmolinets, L.G., Akhmetov, S.M., Luchinskaya, E.N., Terpelets, Z.Z., \& Kunina, M.N. (2017). Mega-Discourse on the Cognitive and Ethno-Cultural Aspects of the Problem of the Functional and Genre Stratification of Modern Sport. Pertanika Journal of Social Sciences and Humanities.

[25] Yazan, B. (2015). The Qualitative Report Three Approaches to Case Study Methods in Education: Yin, Merriam, and Stake. In Teaching and Learning.

[26] Soedarsono, D.K., Mohamad, B., Adamu, A.A., \& Pradita, K.A. (2020). Managing Digital Marketing Communication of Coffee Shop Using Instagram, International Journal of Interactive Mobile Technologies, 14(5), 108118 